\title{
Library services provision for people with visual impairments and in wheelchairs in academic libraries in Tanzania
}

\author{
Rebecca M. Majinge ${ }^{1}$ and Christine Stilwell ${ }^{2}$ \\ majinge@yahoo.com, stilwell@ukzn.ac.za
}

\begin{abstract}
Received: 13 November 2013
Accepted: 13 January 2014
\end{abstract}

\begin{abstract}
This article is based on a study that examined library services provision for people with visual impairments and in wheelchairs in academic libraries in Tanzania. The article looks at access to the information resources available and the layout of library buildings in five universities in Tanzania. The broader issues in this study were grounded in the importance of access to information as a fundamental right and, particularly, in university studies. The study drew on a pragmatism paradigm and the social model of disability of Oliver which emphasises universal access as the norm. Both quantitative and qualitative methods were used to conduct survey and observation-based research. The findings reveal that academic libraries provide services to people with visual impairments and in wheelchairs but these services are not inclusive or universal. The study therefore recommends that academic libraries, as manifest in the social model, should strive to provide inclusive services to all users including people with disabilities. To achieve this universal access requires the formulating of policy regarding provision of library services to people with disabilities, providing adequate budgets and staff training. In addition, practical measures are needed such as constructing library buildings with ramps and maintaining working lifts, acquiring Braille and large print information resources, as well as providing assistive equipment.
\end{abstract}

Keywords: Library services, people with visual impairments, people in wheelchairs, academic libraries, Tanzania, social model

\section{Introduction}

Information is essential to all human beings and every library's aim is to provide the right information at the right time and in the right format to its patrons regardless of race, religion, age, nationality and language. This core function includes the provision of information to people with disabilities. Bagandanshwa (2006) emphasises that all persons have a right to information, regardless of disability. He maintains that information is power because it is the source of knowledge and facts. Similarly the United Nations Educational, Scientific and Cultural Organization (UNESCO: 1997) states that equal right implies that the needs of each individual are of equal importance and that those needs must be the basis for planning. It also infers that all possible resources must be employed to ensure that every individual enjoys equal opportunities for participation. The United Nations (1993) provides "Standard rules on the equalization of opportunities for persons with disabilities" as an instrument for policy-making and for developing technical and economic cooperation. This is not a legally binding instrument but it does embody the commitment of governments to the equalisation of opportunities for persons with disabilities.

The International Federation of Library Associations and Institutions' (IFLA) and UNESCO's "Public library manifesto" (1994) emphasises that libraries must not discriminate on the basis of age, race, sex, religion, nationality, language or social condition. Irvall and Nielsen (2005) provide comprehensive guidelines in their IFLA checklist regarding access to libraries for persons with disabilities. In the same vein, the American Library Association (2001) insists that libraries must not discriminate against individuals on the basis of disability and should ensure that every learner and patron has equal access to library resources. Every library must also provide proper services for those who do not have easy access to them, such as the mentally and physically disabled, the ill and the imprisoned.

Throughout the world people with disabilities face numerous difficulties as they seek to assert their position in a modern, complex and competitive world dominated by able-bodied individuals. People with disabilities are often excluded from social activities and are not treated in the same way as their able-bodied equals. The fact is that, in one way or another, their physical state means that they live a life that is perceived to be different from that of able-bodied people (Ochoggia 2003). Mandesi (2007) adds that people with disabilities face numerous challenges to access opportunities equal to those enjoyed by their peers in day-to-day life. Environmental, physical, legal and institutional barriers are found throughout society, and negative attitudes to persons with disabilities often cause social exclusion and are the hardest to overcome. Mandesi further insists that, for people with disabilities to be treated equally, physical barriers to accessing resources need to be removed and attitudes changed.

Academic libraries, as the providers of information and the heart of higher learning institutions, should be at the forefront of removing the barriers hindering access to information. The social model of disability by Oliver (1990) builds on

1. Rebecca M. Majinge is a PhD candidate in the School of Social Sciences, University of KwaZulu-Natal.

2. Christine Stilwell is Professor Emeritus of the Information Studies Programme, School of Social Sciences, University of KwaZulu-Natal. 
the ideas of the United Kingdom's (UK) Union of the Physically Impaired Against Segregation (UPIAS) founded in the mid-1970s. This model is also endorsed by the UK's Society of College, National and University Libraries' (SCONUL) Access Working Group (Robertson 2012). The model rests on the recognition that people are disabled by social barriers: "If no barrier exists, then a person with an impairment is not prevented from using services" (Robertson 2012:2). Barriers may be physical, or attitudinal, or behavioural. The model requires universal access to libraries, achieved by the construction of ramps alongside stairs, installation of automatic doors, provision of information in Braille and large print, and availability of assistive technologies such as Closed Circuit Television (CCTV), Braille embossers, Screen magnification and JAWS (Shava 2008: 17). Lee (2007: 105) insists that libraries are an important part of society that reflect social trends. The enactment of anti-discrimination acts in many countries is required to make mainstream library services accessible to people with disabilities. Libraries must be designed to be universally accessible, and universal access should be the norm; access for people with disabilities should not be an add-on to existing services. In summary, libraries should have equipment in place that facilitates both easy mobility and easier intellectual access for those who are challenged by visual impairments and rely on wheelchairs (Deines-Jones 2007: 145).

\section{Information provision to people with visual impairments and in wheelchairs in university libraries}

It is the library's role to support lifelong learning and underpin the move towards increased social inclusion and economic participation. Libraries should be resources that are easily accessible and universally available, offering a nonjudgmental environment for people from all backgrounds (Feinberge and Feldma 1996 cited in Davis 2009: 133). In line with this statement, Kharamin and Siamian (2011:368) claim that libraries have to play a key role in building an inclusive society, serving all kinds of users including people with visual impairments. Kharamin and Siamian (2011: 368) further argue that an ideal library service is one where each individual, regardless of the degree of his/her visual impairment or other disability, has access to information resources at the time they are required, in a format that can be used, in the quantities that are needed, and where the needs of the user are understood by the staff.

Using the social model of disability as its base, the academic library should make sure that the information resources it houses are accessible to all library users, including people with visual impairments and in wheelchairs, by creating an enabling user-friendly environment. Deines-Jones (2007: 145) insists that libraries should be designed to be universally accessible, and should have equipment in place to enable all users to get maximum benefit from the library's materials and services. SCONUL's Access Steering Group (Robertson 2012) provides recommendations for good practice regarding a wide spectrum of disabilities. The report enables institutions to identify their current position and recognises that higher education institutions are at different stages of development in respect of inclusive provision. It takes into account physical, practical and financial limitations, as well as the potential for enhancement of provision.

In providing appropriate buildings there should be no architectural barriers which create challenges, for example, too many steps, stairways that are narrow, steps at the entrance of the building and a lack of suitable ramps (Todaro 2005). All sections of the library should be accessible. The available space should be arranged logically with clear signage and a floor plan posted close to the entrance. Service desks should also be located close to the entrance. People in wheelchairs should be able to move around inside the library easily. If the library has more than one level, there should be a lift or ramps for wheelchair users. There should be no raised doorsteps and all doors should have automatic openers. Ideally, shelves should be reachable from a wheelchair (Irvall and Nielsen 2005).

People with visual impairments need information resources which are in Braille and large print. To support this assertion, Gunde (1991) states that the library must provide an appropriate selection of books in formats that are usable by people with visual impairments: large print, audiobooks, talking books, and Braille materials. Similarly, Adetoro (2011) and the American Foundation for the Blind (2013) claim that information materials become useful to people with visual impairments when they are transcribed into alternative formats. Atkinson and Dhiensa (2007) highlight the main alternative to standard print used by people with visual impairments: Braille. Braille is a form of tactile communication used mainly by people who are blind or have very low vision. Braille is based on a twelve-dot cell, two dots wide by six dots high. A combination of dots stands for a letter or sound. Large printed material is another alternative used by partially-sighted users.

In addition, apart from a library having information resources in an alternative format for people with visual impairments, Information and Communication Technology (ICT) plays a large role in assisting people with visual impairments and in wheelchairs to gain access to the information resources available in the library. To support this statement, Atkinson and Dhiensa (2007) state that people who cannot use traditional print can use many of the electronic resources now available, and ICT has been developed to facilitate access to print materials. Tilley, Bruce and Hallam (2007: 64) assert that

by using appropriate assistive technology; which refers to any product, device, equipment, services, strategies and practices that are applied to maintain, increase or improve the functioning of capabilities of individuals with disabilities libraries can improve information access and quality of life for large numbers of their patrons.

In line with this statement, Babalola and Haliso (2011) recommend that libraries take advantage of advances in ICT to increase information access for people with visual impairments. In addition a broad range of assistive technologies such as Closed Circuit Television (CCTV), Braille embossers, Screen magnification and JAWS are now available to 
provide access to information in electronic databases and on the internet, thereby giving users with visual impairments opportunities equal to those of the sighted.

\section{Context and scope of the study}

This study focuses on library services provision for people with visual impairments and in wheelchairs with regard to the layout of library buildings and access to information resources. The study addresses people who are partially sighted or totally blind and those in wheelchairs with physical disabilities. The geographic scope of the study was limited to Tanzania, covering three administrative regions: Dar es Salaam, Dodoma and Tanga. The Ministry of Education and Vocational Training (MoEVT) as well as five universities in these regions were studied. These institutions are the University of Dar es Salaam, Open University of Tanzania (OUT), Dar es Salaam University College of Education (DUCE), St. John's University of Tanzania (SJUT) and Sebastian Kolowa Memorial University (SEKOMU).

The University of Dar es Salaam library is the largest library in Tanzania and serves more than 7,000 users comprising academic staff, researchers and students. It also assists a significant number of local users, ministries, research institutes and other institutions of higher learning, as well as regional and international researchers (Nawe 2003). The mission of the library is to become the centre of excellence in information provision in the country, and to provide scholarly information resources to its current and future academic communities to support the core functions of the university, which are teaching, research and service to the community (University of Dar es Salaam 2013).

The main library of the Open University of Tanzania is located at OUT's headquarters in Dar es Salaam. It provides library and information services to staff and students residing in Dar es Salaam. The university has placed books and other reading materials in those regions where there are branches of the Tanzania Library Services (public library). These collections are specifically for OUT students and are managed by Tanzania Library Services staff (Msuya and Maro 2002:185).

Dar es Salaam University College of Education Library was established in 2005, following the establishment of DUCE. It is a learning resource centre which provides various information resources and services to the university community to support learning, teaching, consultancy and the general pursuit of knowledge. The mission of the library is to satisfy the user's information needs through developing relevant collection information resources in all formats such as print and electronic resources (University of Dar es Salaam 2007; Dar es Salaam University College of Education 2013).

Sebastian Kolowa Memorial University Library is located on campus B within the university. The library supports the core functions of the university which are teaching, research and consultancy. The library has a collection of books, print journals and audio visual materials such as CD-ROMs. It also subscribes to full-text electronic journals and databases (Sebastian Kolowa University College 2012).

St. John's University of Tanzania library is located within the university. It is an essential part of students' academic life and the general academic community as a whole. The library serves a population of approximately 3,000 students as well as over 100 academic staff members and some external borrowers. The library has 110,000 volumes covering diverse scholarly information resources that meet the teaching and learning needs of both students and lecturers (St. John's University of Tanzania 2011).

Although academic libraries in Tanzania provide services to the universities' communities of users, the services are not inclusive to people with disabilities. The services which they provide are for abled-bodied people. This impression is supported by Ndumbaro (2009) and Bagandanshwa (1998) who note that library services for people with visual impairments, in particular, are significantly lacking in Tanzania.

\section{Statement of the problem}

Personal experience in Tanzanian academic libraries suggests there is a lack of access to services that meet the needs of users with visual impairments and in wheelchairs. Bagandashwa (1998) studied library services for visual impaired and blind people in Tanzania and notes that library services for them are significantly lacking. Similarly, Ndumbaro (2009) observes that in Tanzania, generally, library and information services are planned without considering the needs of people with visual impairments. These services appear to be based on the assumption that people with visual impairments do not exist, or do not need the services. In addition, the United Republic of Tanzania National Policy on Disability (2004) states openly that the education system in Tanzania does not allow equal access for children with disabilities. Almost all school facilities at all levels are physically inaccessible for those with disabilities. Teacher education and the curriculum do not incorporate the needs of those with disabilities. The National Policy on Disability, however, does support, on paper, the need for all public buildings to be built to cater for the needs of those with disabilities. In practice, however, stairs, narrow doorways and toilets remain inaccessible for the majority of persons with disabilities in most academic library buildings and schools. This is due to the fact that the general recommendations of the policy do not specifically address the provision of library services to people with disabilities.

The purpose of the study upon which this article is based was to investigate library services provision in academic libraries in Tanzania for people with visual impairments and those in wheelchairs who had physical disabilities such as paraplegia. The term "visual impairment" refers to anyone who has difficulty reading an ordinary font size on paper or on screen (Kinnell, Yu and Creaser 2000). A wheelchair user is a person who has difficulty in walking or moving around and uses a wheelchair for mobility (World Health Organization 2008:11). The study investigated whether information resources are available to these groups of people, how good access to these resources are, and the physical layout of the library buildings. The specific objective of the study was to examine the physical layout of academic libraries in Tanzania; to find out whether information resources are provided for people with visual impairments; to establish the 
challenges facing people with visual impairments and in wheelchairs in accessing and using academic library services; to examine the role of ICT in facilitating provision of information resources to people with visual impairments and in wheelchairs; as well as to identify challenges experienced by the academic library in seeking to provide services to people with visual impairments and in wheelchairs.

\section{Methodology}

This study was conducted within a pragmatism paradigm. The intention was to address the problems which people with visual impairments and in wheelchairs face by applying various suitable approaches to data gathering. Both quantitative and qualitative methods were used. The study was conducted in three administrative regions: Dar es Salaam, Dodoma and Tanga. In these regions, five universities were studied: University of Dar es Salaam, Open University of Tanzania, Dar es Salaam University College of Education, Sebastian Kolowa Memorial University and St. John's University of Tanzania. In addition, the Special Needs Education Unit for Disabilities at the Ministry of Education and Vocational Training was included in the study. The population of the study included library directors, other professional library staff, disability unit staff, and people with visual impairments and in wheelchairs. People from the Ministry were included through a staff member from the Ministry's Special Needs Education Unit and the various universities' disability unit population. Snowball sampling was used to identify the people with visual impairments and in wheelchairs because the researcher had no knowledge of the actual disability population. This sampling was used to ensure that the estimated number of library users who had visual impairments and users in wheelchairs was reached. Questionnaires, interview schedules and an observation checklist were used to gather data. Data gathered through questionnaires were analysed using descriptive statistics facilitated by SPSS and data gathered through interviews were analysed using thematic analysis.

Of the 139 copies of the questionnaire for library staff, $113(81 \%)$ completed instruments were returned; fifteen $(78 \%)$ of nineteen copies of the respective questionnaire were returned by disability unit staff and six $(85.7 \%)$ of seven copies of the last questionnaire were returned by people in wheelchairs. In addition fifty-seven (85\%) of sixty-seven respondents with visual impairments and five (100\%) directors from five universities were interviewed. Tables 1 and 2 below give the populations of library staff and people with disabilities who were surveyed at the five universities. In addition, fourteen staff from the disability units and the one head of a Special Needs Education Unit, who are not indicated in the tables, were surveyed.

Table 1 Population of library staff

\begin{tabular}{lcccc}
\hline \multicolumn{5}{c}{ Library staff } \\
SN & University & Expected respondents & Actual respondents & Source of data \\
\hline 1 & UDSM & 77 & 66 & Library annual report 2011 \\
2 & DUCE & 24 & 17 & Staff list 2012 \\
3 & OUT & 18 & 13 & Staff list 2012 \\
4 & SJUT & 13 & 11 & Staff list 2012 \\
5 & SEKOMU & 7 & 6 & SEKOMU prospectus 2011/2012 \\
Total & & $\mathbf{1 3 9}$ & $\mathbf{1 1 3}$ & \\
\hline
\end{tabular}

Table 2 Population of people with visual impairments and in wheelchairs

\begin{tabular}{|c|c|c|c|c|}
\hline \multirow[b]{2}{*}{ SN } & \multicolumn{4}{|c|}{ People with visual impairments or in wheelchairs } \\
\hline & University & Expected respondents & Actual respondents & Source of data \\
\hline 1 & UDSM & 27 & 26 & Library staff \\
\hline 2 & DUCE & 10 & 9 & Library staff \\
\hline 3 & OUT & 20 & 10 & Library Staff \\
\hline 4 & SJUT & 2 & 2 & Library staff \\
\hline 5 & SEKOMU & 17 & 16 & University staff \\
\hline Total & & 76 & 63 & \\
\hline
\end{tabular}

\section{Findings and discussion}

\subsection{Services for people with visual impairments and in wheelchairs.}

Directors of the libraries were asked in an interview whether they provide services to people with visual impairments and in wheelchairs. The responses were positive although it was explained that, in most cases, the services are provided by the disability units, which fall under the school of education administratively. Materials and equipment suitable for people with visual impairments are housed in the disability units. 
Library staff (113) were asked whether the library provides services to people with visual impairments and in wheelchairs. The responses were as follows: seventy-one (63\%) responded positively while forty-one (37\%) responded negatively (see figure 1).

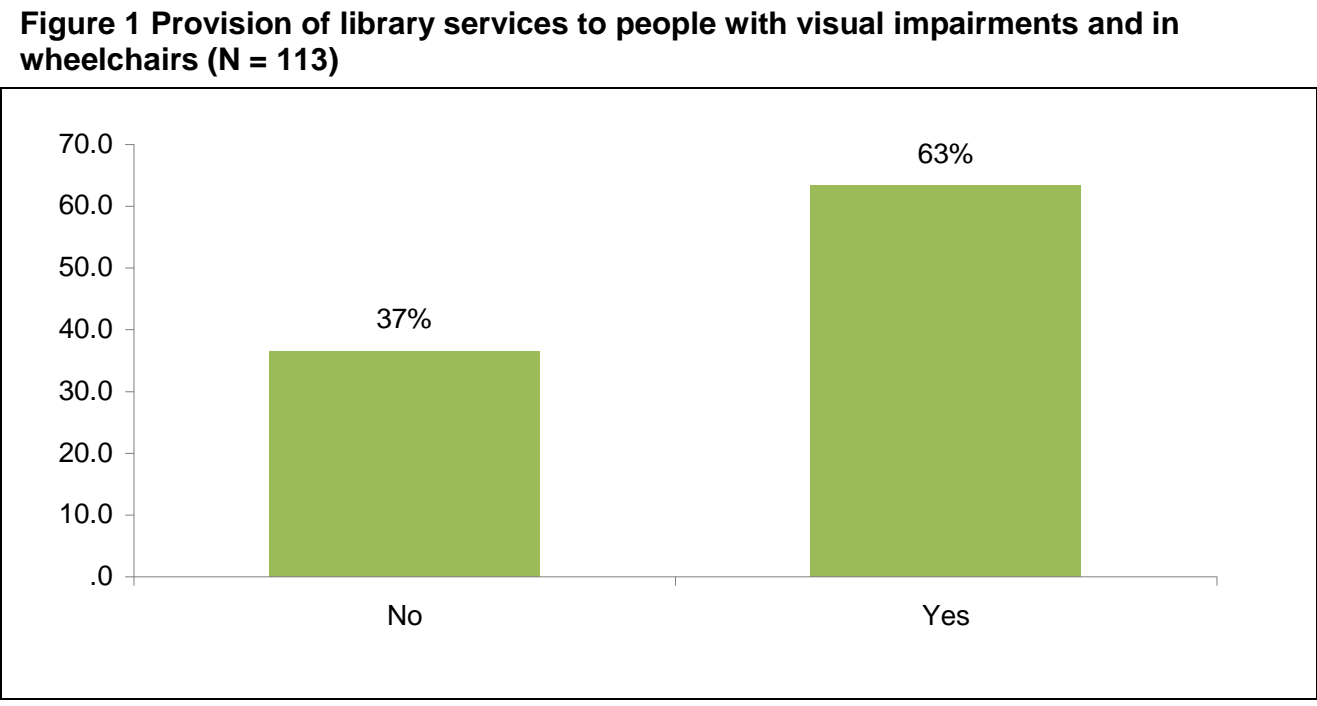

People in wheelchairs (six) were asked whether they used library services. The responses were as follows: four $(67 \%)$ responded positively while two (33\%) responded negatively. Those who responded positively explained that they use the library for borrowing books and other information resources as well as searching the internet. Respondents who responded negatively said that they do not use the library because the infrastructure does not allow them to access the information housed in the library (see table 3).

Table 3: Library services to people in wheelchairs $(\mathrm{N}=6)$.

\begin{tabular}{lcc}
\hline Responses & Frequency & Percentage \\
\hline Yes & 4 & $67 \%$ \\
No & 2 & $33 \%$ \\
Total & 6 & $100 \%$ \\
\hline
\end{tabular}

In addition, people with visual impairments were asked in their interviews whether they use the library services. Of the fifty-seven, forty-seven (82\%) responded that they use the library when they want to borrow books and other information resources. Another ten (18\%) said that they do not use the library services because there are no information resources in their required format in the library and the layout of the library buildings does not allow them to access information resources.

It was evident from the findings that, although academic libraries in Tanzania provide services to people with visual impairments and in wheelchairs, the services are not inclusive or universal. The services which they provide are for ablebodied people. This finding concurs with the findings of Ndumbaro (2009) who observed that, in Tanzania generally, library and information services are planned without considering the needs of people with visual impairments. These services appear to assume that people with visual impairments do not exist, or if they do exist, they do not need such services. Bagandashwa (1998) notes that library services for people with visual impairments are significantly lacking in Tanzania. In a similar way, Grobbelaar-du Plessis and van Reenen (2011: xvi) observe that, for a large majority of people with disabilities, public facilities, transport, training, working opportunities, communication and access to information are unavailable or inaccessible. In addition, Alemna (n.d.: 258) claims that in most African countries, library and information services to people with visual impairments are almost non-existent.

\subsection{Professional services}

The directors of the libraries interviewed were asked if they have staff who are trained to assist people who have visual impairments or are in wheelchairs. The responses were negative, indicating that no specially trained and experienced library staff assist such people. The researcher also noted that staff who provide services to people with visual impairments and in wheelchairs are not trained in the special needs of people with visual impairments and in wheelchairs.

Library staff was also asked if the library has staff that are trained and experienced in providing services to people with visual impairments and in wheelchairs. Of the 113, 104 (92\%) responded negatively, while nine (8\%) responded positively. Those who responded negatively stated that in their academic libraries no trained and experienced staff assist these users. Respondents further explained that the library programmes and curricula of universities at all levels do not include a component on special needs for people with disabilities. Those who responded positively indicated that 
academic libraries do have trained and experienced staff who provide for or assist users with visual impairments and in wheelchairs. Figure 2 below depicts the responses of library staff on this issue.

Figure 2 Availability of trained and experienced staff who provided for or assist users with visual impairments and in wheelchairs in the use of library services $(\mathrm{N}=113)$

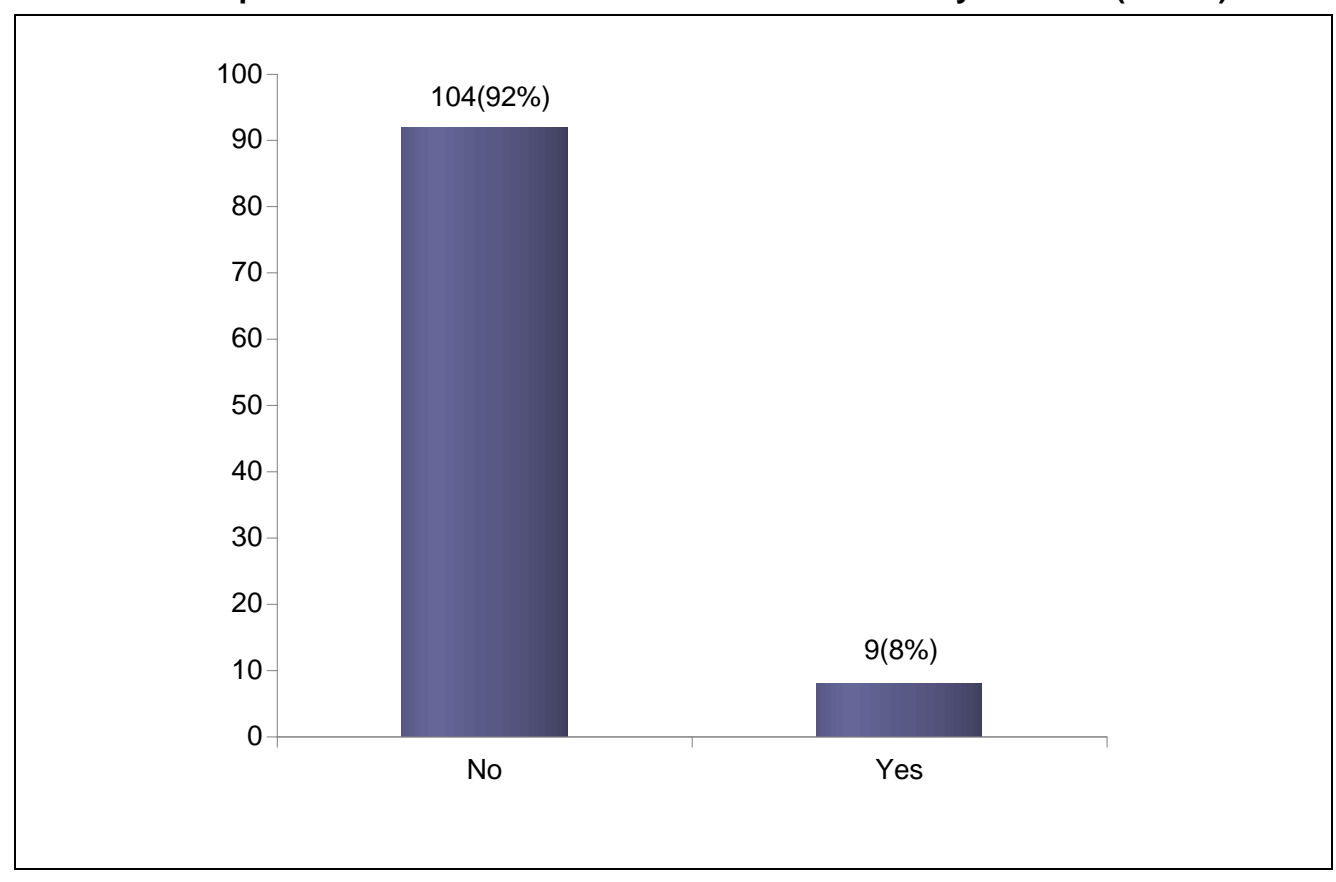

The study found that in academic libraries in Tanzania no trained and experienced staff assist users with visual impairments and in wheelchairs. The study findings are in line with those of Bagandanshwa (1998) who notes that there is no one to guide and help people with visual impairments and, as a result, it is impossible for people with disabilities to make use of the library's services. In the same vein, Arjomand (1993) and Hashemi (1994), cited in Bodaghi and Zainab (2012:243-244), observe that there are untrained staff who are unable to assist people with disabilities. Similarly, Kaijage (1991) points out that there is a lack of properly trained staff who might be in position to be considerate and understanding of people with visual impairments, as well as being able to address their information needs. In line with this, Alemna (n.d.: 259) indicates that there is a lack of properly trained library personnel. In most library schools in Africa, the curricula are geared towards conventional librarianship courses. For this reason, library staff are often unable to address the needs of people with visual impairments.

\subsection{Library staff attitudes}

Staff providing library services were asked about their attitudes to people with visual impairments and in wheelchairs. They were asked to respond to the statement:

To what extent do you agree with the following statement: generally the attitude of most library staff towards providing library services to people with visual impairments and in wheelchairs is not good.

Responses were as follows: forty-seven (42\%) disagreed; nine (8\%) had no opinion; twenty-six (23\%) agreed; and twelve $(10 \%)$ strongly agreed. Responses indicate that the majority of library staff think that the staff's attitude is good, although there are some who disagree and believe that staff's attitude is not good. Figure 3 below shows their responses.

The people in wheelchairs were asked similarly if they agreed with the statement that "the attitude of library staff towards people with visual impairments and in wheelchairs in provision of library services is principally negative" and the responses were as follows: of the six, five (83\%) strongly agree and one $(17 \%)$ cited "no opinion". Table 4 shows their responses. People with visual impairments were also interviewed and all fifty-seven (100\%) responded that there are some library staff who are positive and others who are negative about providing library services to people with visual impairments. Respondents explained further that, to those staff who are positive to them, they are also positive in return and to those who are negative, they are negative. One student complained that:

There are some library staff who are very negative to us when you ask for help - it's like you are disturbing them. But some are positive and helpful and when you ask for help, you get assistance.

The findings of the study show that not only library staff have negative attitudes; the whole society displays a negative attitude, as one student with visual impairments complained: 
My family said [that] I have already died because I'm visually impaired and [that] I can't do anything, but after my struggle and performing well in my studies ... they started realising that I can do something and be helpful to the family.

Another student complained that even lecturers have negative attitudes towards her and said:

Sometimes when the lecturers [are] teaching they ... write a spelling of [a] word .... . We are visually impaired. How can we know what is written? It is affecting us academically.

Another student contended that:

We are not happy with the names [given] to us when we [use] the services in some areas. You hear people [saying], "Ambulance is passing, let ambulance go first". That means we don't need to wait for the services.

The findings indicate that positive attitudes of both library staff and people with visual impairments and in wheelchairs are required to facilitate maximum usage and provision of library services to people with visual impairments and in wheelchairs. Alemna (n.d.: 260) contends that positive attitudes are an essential ingredient in making the library available to people with visual impairments. Dequin, Schilling and Huang (1988) also claim that positive attitudes of academic librarians towards disabled students are essential for the provision of adequate library services to meet their needs. Seyama (2009) points out that, in order to provide effective library services to students with visual impairments, it is essential that all staff have appropriate attitudes towards them.

Figure 3 Attitudes of library staff $(\mathrm{N}=113)$



Table 4 Attitudes of people in wheelchairs $(\mathrm{N}=6)$

\begin{tabular}{lcc}
\hline Responses & Frequency & Percentage \\
\hline Strongly agree & 5 & $83 \%$ \\
No opinion & 1 & $17 \%$ \\
Total & 6 & $100 \%$ \\
\hline
\end{tabular}

\subsection{Policy environment}

Directors of the libraries interviewed were asked whether they had policy relating to library services provision for people with visual impairments and in wheelchairs. They responded that they do not have policies in place, but the director of the Open University of Tanzania said they had started writing a policy describing services to people with disabilities and that the policy was in its final stages. All of the above responses show that there is no policy in academic libraries in Tanzania regarding library services for people with disabilities, apart from the Open University of Tanzania's policy which is in its final stages of formulation.

Library staff was asked whether academic libraries in Tanzania had policy addressing services regarding people with visual impairments and in wheelchairs. Responses from the 113 were as follows: 111 (98\%) responded negatively whereas two (2\%) responded positively. Responses are shown in figure 4. 
A similar question, about whether they had policy relating to library services provision for people with disabilities, was asked of the staff of the special needs education units for disability. Responses from the fifteen were as follows: twelve $(80 \%)$ responded negatively whereas three $(15 \%)$ responded positively. Those who responded negatively indicated that there was no policy and they explained that currently there were no plans to formulate policy regarding library services provision for people with disabilities. Respondents who indicated a positive response stated that an initiative to formulate a policy regarding library services was underway. Responses are shown in table 5.

Figure 4 Whether the library has a policy describing services regarding people with visual impairments and in wheelchairs $(\mathrm{N}=113)$

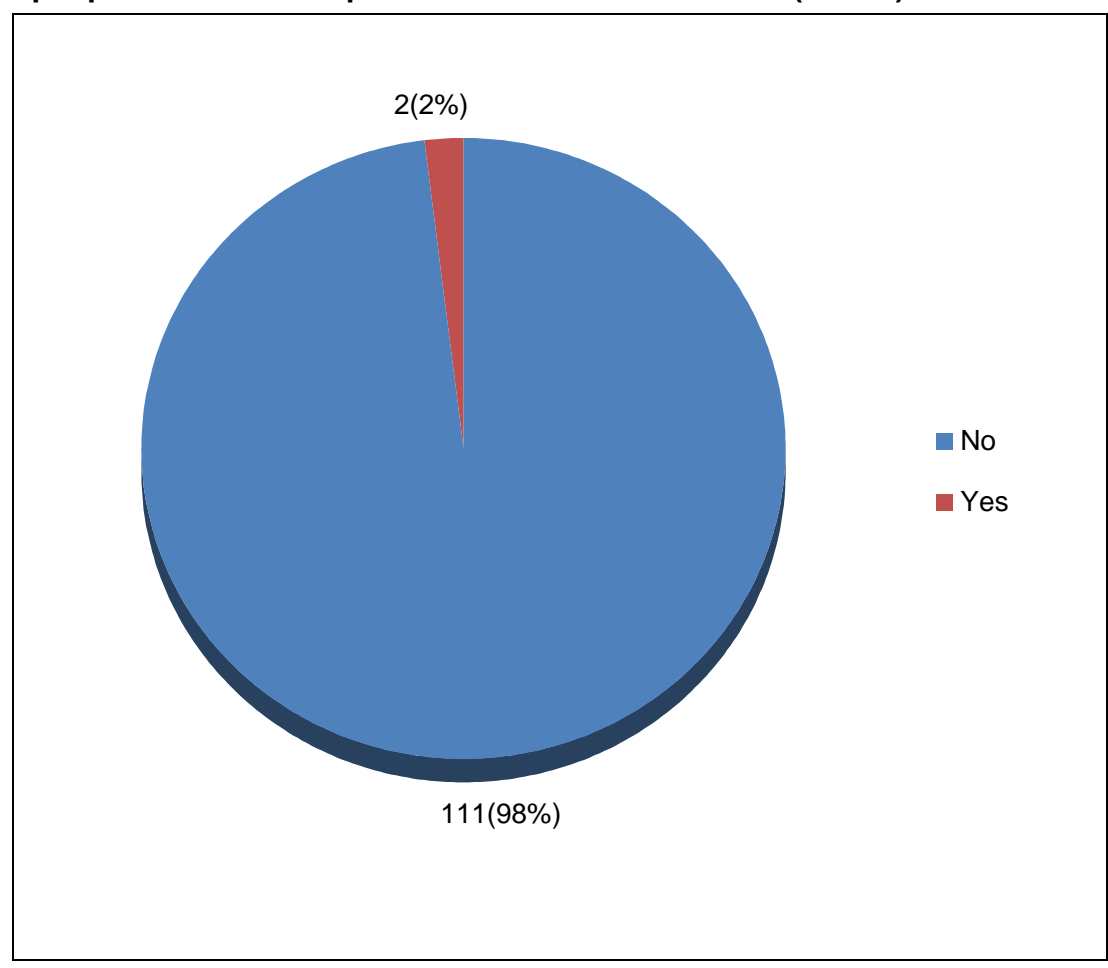

Table 5 Whether Special Needs Unit has policy relating to library services provision for people with disability ( $N=15)$

\begin{tabular}{lcc}
\hline Responses & Frequency & Percentage \\
\hline No & 12 & $80 \%$ \\
Yes & 3 & $20 \%$ \\
Total & 15 & $100 \%$ \\
\hline
\end{tabular}

It was observed that the Tanzanian National Policy on Disability of 2004 does not address library services to people with disabilities and there are no library policies in academic libraries in Tanzania regarding library services for people with disabilities. The findings concur with those of Ndumbaro (2009) who says that the national policy is not clear on the availability of library and information services. In the same vein, Bath (2005), cited in Bodaghi and Zainab (2012), claims that there is a lack of policies, procedures or guidelines that cater for the needs of people with disabilities. UNESCO (1997) asserts that only a few universities have a written policy regarding disabled students. According to UNESCO, the universities which had no policy in the late 1990s regarding students with disabilities were the University of Asmara in Eritrea; Addis Ababa in Ethiopia; the University of Science and Technology in Ghana; Moi University and University of Nairobi in Kenya; the University of Malawi; the University of Mauritius; South Africa's Universities of the North, Port Elizabeth and the Free State; the Mbarara University of Science and Technology; Uganda's Martyrs University; and the National University of Science and Technology in Zimbabwe.

\subsection{Building structures}

Directors of the libraries were interviewed and asked if the layout of the library buildings allows people with visual impairments and in wheelchairs to access the information resources housed in the library. The responses were negative. Library staff were asked the same question. Of the 113 respondents, $101(89 \%)$ respondents responded negatively and twelve $(11 \%)$ responded positively. Responses are shown in figure 5.

In addition, fifty-seven people with visual impairments were interviewed and they responded that the layout of the library buildings does not allow people with visual impairments to access information resources housed in the library 
easily. The same question was asked of people in wheelchairs. Four $(67 \%)$ responded negatively and two (33\%) responded positively. Table 6 below indicates their responses.

The layout of library buildings in academic libraries does not allow people with visual impairments and in wheelchairs easy access to the information resources housed in the library. In addition, for all the universities investigated, it was noted that there are no functioning lifts and ramps which enable people with visual impairments and in wheelchairs to reach upper floors where information resources or services are located. The findings concur with those of Bagandanshwa (1998) who observes that the library buildings in most cases are unsuitable for the mobility needs of people with visual impairments. They have no rail-marks for easy identification, and there are many stairs and unprotected embankments. Kaijage (1991), Ndumbaro (2009) and Leong and Higgins (2010) also note that the design of the library buildings does not provide easy access for university students with visual impairments. Similarly, Onatola (2007:96) claims that the present situation in all universities in Nigeria is such that students and staff who use wheelchairs have to be physically carried when they want to access public facilities such as libraries and lecture rooms. The alternative arrangement is to restrict users of wheelchairs to the ground floor, regardless of where the materials which they need are housed.

Figure 5 Access for persons with disabilities facilitated by the layout of library buildings $(\mathrm{N}=113)$

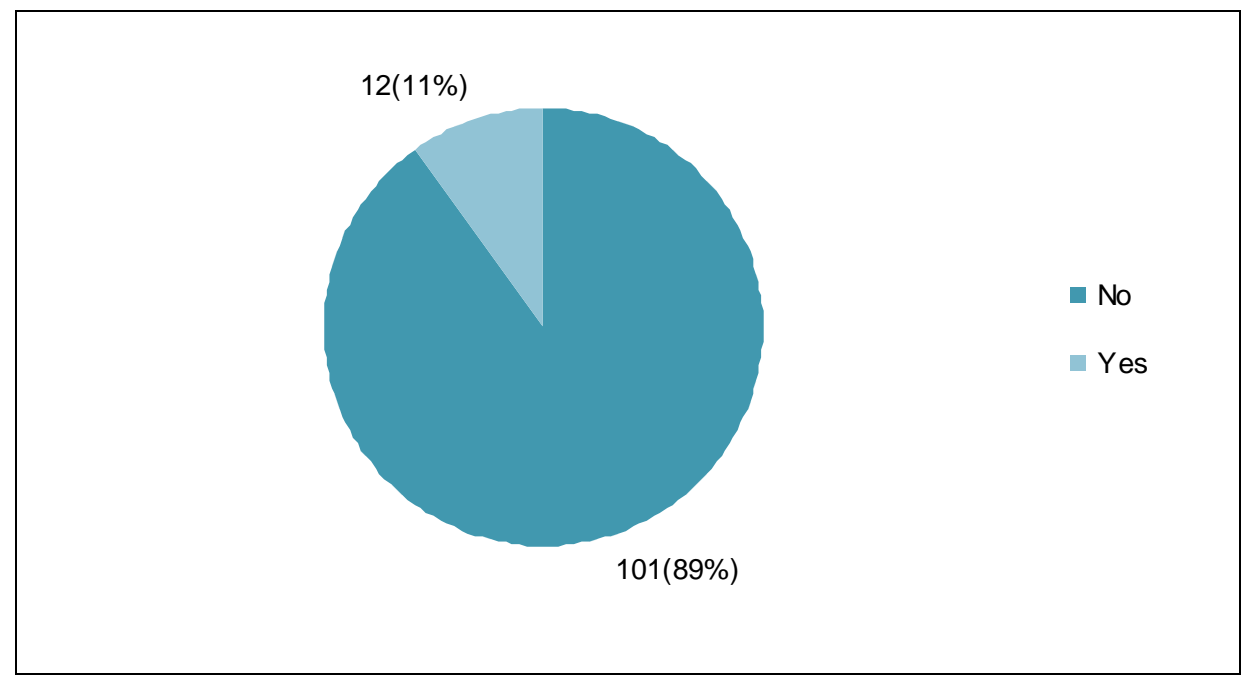

Table 6 Layout of the library buildings $(\mathrm{N}=6)$

\begin{tabular}{lcc}
\hline Responses & Frequency & Percentage \\
\hline No & 4 & $67 \%$ \\
Yes & 2 & $33 \%$ \\
Total & 6 & $100 \%$ \\
\hline
\end{tabular}

\subsection{Information resources}

Library staff were asked whether the information resources available in the library are suitable for people with visual impairments. Responses from the 113 were ninety-nine (88\%) who responded negatively and fourteen (12\%) who responded positively. Figure 6 indicates the responses.

Figure 6 Alternative materials for people with visual impairments $(\mathrm{N}=113)$

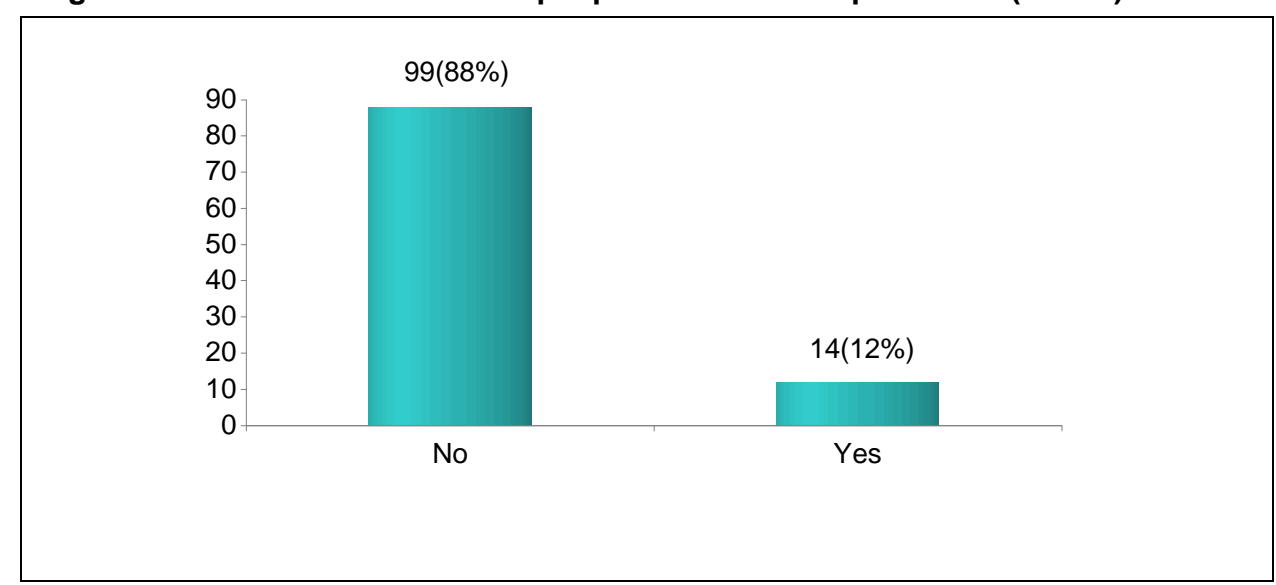


Library directors were also interviewed about whether academic libraries have alternative material for people with visual impairments. Despite the few positive responses from library staff, the directors' responses were negative, indicating that they think there are no alternative materials for people with visual impairments. In addition, people with visual impairments were also interviewed to establish whether academic libraries have alternative materials. Again, despite the positive responses above, all fifty-seven (100\%) people with visual impairments responded negatively.

The findings confirm that there are no alternative information resources for people with visual impairments in academic libraries in Tanzania and therefore people with visual impairments use normal print information resources for which the universities employ readers who read for them. These readers are either only a few in number or completely lacking in all academic libraries investigated. This finding resonates with the findings of Tungaraza (2010) who notes that students with visual impairments at the University of Dar es Salaam depend on readers to read for them since the library does not have books in Braille. In the same vein, Kaijage (1991), Ndumbaro (2009), Bagandanshwa (1998), Shunmugam (2002) and Ochoggia (2003) claim that there are no information resources in alternative formats for people with visual impairments in the academic libraries.

\subsection{The role of ICT}

Library staff were asked whether ICT facilities assist people with visual impairments and in wheelchairs with information provision in academic libraries in Tanzania. Responses from the 113 were as follows: 102 (90\%) responded positively while eleven (10\%) responded negatively (see figure 7 ).

\section{Figure 7 ICT facilities assists provision of information to people with visual impairments and in wheelchairs $(\mathrm{N}=113)$.}

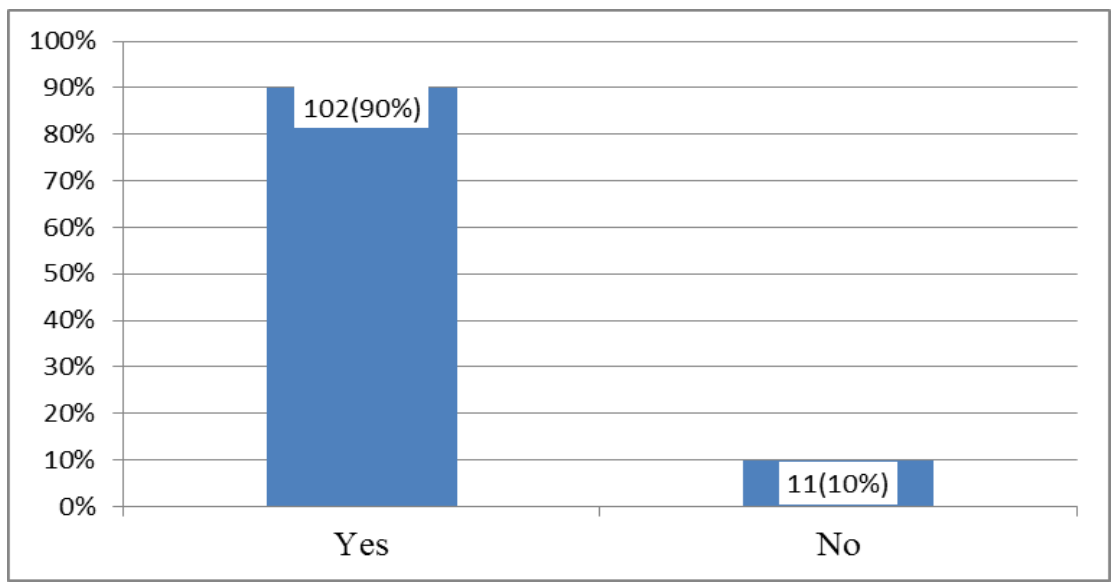

The same question was posed to people in wheelchairs: whether ICT facilities assist access to the information needed. All six (100\%) people in wheelchairs responded positively, indicating that ICT equipment assists them in accessing information resources. In addition, they explained that ICT equipment facilitates easy retrieval of information as well as remote access to information. Responses are shown in table 7.

People with visual impairments were also interviewed about whether ICT equipment could facilitate information access for them. All fifty-seven (100\%) responded positively. They explained that ICT helps them to access information easily and independently, and also converts information into a suitable format.

Table 7 Responses of people in wheelchairs on whether ICT facilities will assist them $(\mathrm{N}=6)$

\begin{tabular}{lll}
\hline Responses & Frequency & Percentage \\
\hline Yes & 6 & $100 \%$ \\
Total & $\mathbf{6}$ & $\mathbf{1 0 0 \%}$ \\
\hline
\end{tabular}

The study confirms that ICT equipment facilitates library services' provision of information resources to people with visual impairments and in wheelchairs easily and independently as well as converting information resources into the formats suitable for people with visual impairments. To support this statement, Dragoicea, Sacala, Cojocaru, Shivarov and Balan (2009) claim that assistive technologies are prerequisites for people with visual impairments to access information resources housed in academic libraries. Bagandanshwa (2006b) insists that technology is appropriate for people with visual impairments for accessing and using the services.

\section{Conclusion and recommendations}

The study concluded that academic libraries should provide inclusive and universal services to people with visual impairments and in wheelchairs as access to information is a fundamental human right and academic libraries exist to 
support the learning, teaching, research and consultancy of all in the university community, including people with visual impairments and in wheelchairs. For academic libraries to provide services which are inclusive and universal, the layout of library buildings needs to include having working lifts and ramps for people with visual impairments and in wheelchairs so that they can easily access the information resources housed in the library. In addition, information resources which are in Braille and large print are required for people with visual impairments; assistive equipment is also needed to enable them to read the information resources available.

Furthermore, staff trained and experienced in special needs are required. This will be possible if the library programmes and curricula of library and information studies in all universities include components on special needs for people with disabilities at all levels of qualification. Positive attitudes to both library staff and people with visual impairments and in wheelchairs are needed to allow access and use of information resources. In addition, policies addressing library services for people with disabilities, as well as the adequate allocation of funds, are needed to enable academic libraries to provide universal services to people with visual impairments and in wheelchairs.

\section{References}

Adetoro, N. 2011. Availability and use of information materials by persons with visual impairments in Nigeria. Information, society and justice, 4(2): 5-18.

Alemna, A. n.d. Library provision for the blind in Africa. [Online]. http://forge.fh-potsdam.de/ IFLA/INSPEL/93-4alan.pdf. (29 July 2013).

American Foundation for the Blind. 2013. Educational interventions for students with low vision. [Online]. http://www.afb.org/section.aspx?FolderID=3\&SectionID=44\&TopiclD=189\&DocumentID=2646. (19 March 2013).

The American Library Association (ALA). 2001. Library services for people with disabilities policy. [Online]. http://www.ala.org/ala/ascla/asclaissues/libraryservices.cfm. (16 November 2010).

Atkinson, M. T. and Dhiensa, J. 2007. Improving library services to people with print disabilities: the role of technology in public libraries In Improving library services to people with disabilities. C. Deines-Jones, Ed. Oxford: Chandos Publishing. 1-20.

Babalola, Y. T. and Haliso, Y. 2011. Library and information services to the visually impaired: the role of academic libraries. Canadian social science, 7(1): 140-147.

Bagandanshwa, E.T.T. 1998. Library services for visually impaired and blind people in Tanzania. Huria: journal of the Open University of Tanzania, 2(1): 53-59.

Bagandanshwa, E.T.T. 2006. Technologies deployed by visually impaired and blind people in Tanzania to access information. Journal of issues and practice in education, 1(1): 79-87.

Bodaghi, N. B. and Zainab, A. N . 2012. Accessibility and facilities for the disabled in public and university library buildings in Iran. Information development, 29(3): 241-250.

Dar es Salaam University College of Education. 2013. Library Information Services. [Online]. http://ducelibrary.wordpress.com/about/ (10 April 2013).

Davis, G. 2009. Towards a transformed library and information sector in South Africa: rethinking roles. South African journal of library and information science, 75(2): 131-137.

Deines-Jones, C. Ed. 2007. Improving library services to people with disabilities. Oxford: Chandos Publishing.

Dequin, H.C., Schilling, I. and Huang, S. 1988. The attitudes of academic librarians towards disabled persons. The journal of academic librarianship, 14(1): 28-31.

Destounis, P., Garofalakis, J., Mavritsakis, G., Rigou, M., Sirmakessis, S. and Tzimas, G. 2004. Designing for ease is designing for all experiences from a simplified office suite. Information technology and people, 17(3): 286 -302.

Dragoicea, M., Sacala, M.D., Cojocaru, A., Shivaron, N. and Balan, C. 2009. Designing mobile assistive technologies in the model driven development framework. Proceedings of the $1^{\text {st }}$ International Conference on Manufacturing Engineering, Quality and Production Systems. Romania: Transilvania University of Brasov.

Grobbelaar-du Plessis, I. and Van Reenen, T. Eds. 2011. Aspects of disability law in Africa. Pretoria: Pretoria University Law Press.

Gunde, M.G. 1991. Every librarian should know about the Americans with Disabilities Act. American Libraries, 22(8):380398. Available: http://www.jstor.org/stable/25632347 (21 February 2012).

International Federation of Library Association/United Nations Educations, Scientific and Cultural Organization (IFLA/UNESCO). 1994. Public library manifesto. [Online]. http://archive.ifla.org/VII/s8/unesco/eng.htm (19 March 2012).

International Labour Organization (ILO). 2004. United Republic of Tanzania: employment of people with disabilities: the impact of legislation (East Africa). Geneva: ILO.

Irvall, B and Nielsen, G.S. 2005. Access to libraries for persons with disabilities: checklist. International Federation of Library Associations and Institutions, IFLA professional Report No. 89. The Hague: IFLA. Available: http://www.ifla.org/files/assets/hq/publications/professional-report/89.pdf (12 January 2014).

Kinnell, M., Yu, L. and Creaser, C. 2000. Public library services for visually impaired people. Leicestershire: Library and Information Statistics Unit (LISU).

Lee, Y.S. 2007. Finding the means to improve services In Improving library services to people with disabilities. DeinesJones, C. Ed. Oxford: Chandos Publishing. 105- 122.

Leong, I.C.B. and Higgins, S.E. 2010. Public library services for wheelchair-bound young people in Singapore. London: Routledge 
Kaijage, J.J.L. 1991. An assessment of library and information services for the visually impaired: with particular reference to information needs of visually impaired university students and information plans for Tanzania. Master's dissertation. University College of Wales.

Kharamin, F. and Siamian, H. 2011. The survey of public library services for visually impaired and blind in public libraries: case study of Mazandaran province librarian, Iran. Singapore: International Association of Computer Science and Information Technology (IACSIT) Press.

Mandesi, G.K. 2007. Manual on HIV/AIDS awareness and disability rights. Dar es Salaam: Rehabilitation International, Disabled Organization for Legal Affairs and Social Economic Development (DOLASED).

Msuya, J. and Maro, F. 2002. The provision of library and information services to distance learners: the Open University of Tanzania (OUT). Libri, 52: 183-191.

Nawe, J. 2003. Planning and policy issues in academic libraries in Tanzania. Library management, 24(8/9): 417-422.

Ndumbaro, R. 2009. Library and information services provision for people with visual impairment in selected university and public libraries in Tanzania. Master's dissertation. University of Dar es Salaam.

Ochoggia, R.E. 2003. Persons with Disabilities Bill 2002: implications concerning visual disabilities for academic library and Information Services in Kenya. New Library World, 104(1190/ 1191): 307-312.

Oliver, M. 1990. The politics of disablement: a sociological approach. New York: St. Martin's Press.

Onatola, A. 2007. Reaching people with disabilities in developing countries through academic libraries. In Improving library services to people with disabilities. Deines-Jones, C. Ed. Oxford: Chandos Publishing. 87-104.

Robertson, L. 2012. Access for library users with disabilities. [Online]. http://www.sconul.ac.uk/content/access-libraryusers-disabilities (12 January 2014).

Sebastian Kolowa University College. 2012. Prospectus 2012/ 2013. [Online]. http://www.sekomu.ac.tz (11 March 2013).

Seyama, L. G. 2009. Information seeking behaviour of students with visual impairments: a case study of the University of KwaZulu-Natal, Pietermaritzburg. Master's dissertation. University of KwaZulu-Natal.

Shava, K. 2008. How and in what ways can western models of disability inform and promote the empowerment of disabled people and their participation in mainstream Zimbabwean society? Master's dissertation. University of Leeds.

Shunmugam, M. 2002. An exploration of the barriers, as experienced by visually impaired students studying at the University of Natal. Master's dissertation. University of Natal.

St. John's University of Tanzania. 2011. Prospectus 2011-2012. Dodoma: The Office of the Deputy Vice Chancellor Academic.

Tilley, C.M., Bruce, C.S. and Hallam, G. 2007. Adaptive technology for people with physical disabilities using information and communications technology In Improving library services to people with disabilities. Deines-Jones, C. Ed. Oxford: Chandos Publishing. 65-86.

Todaro, A.J. 2005. Library services for people with disabilities in Argentina. New library world, 106(1212/1213): 253-268.

Tungaraza, F.D. 2010. Accomplishments and challenges facing students with disabilities at the University of Dar es Salaam: thirty years of navigating the hill. Paper in education (PED). 29. Dar es Salaam: University of Dar es Salaam.

United Nations. 1993. The standard rules on the equalization of opportunities for persons with disabilities [Online]. http://www.un.org/esa/socdev/enable/dissre00.htm (12 January 2014).

United Nations Educational, Scientific and Cultural Organization. 1997. Disabled students at universities in Africa. Harare: UNESCO.

United Republic of Tanzania. 2004. National policy on disability. Dar es Salaam: Ministry of Labour, Youth and Development and Sports.

University of Dar es Salaam. 2007. Undergraduate prospectus 2007/8-2009/10. Dar es Salaam: The Office of the Deputy Vice Chancellor, Research and Knowledge Exchange. Available: http://www.uaut.ac.tz/uaut/prospectus.pdf (11 March 2013).

University of Dar es Salaam. 2013. Library information services. [Online]. http://library.udsm.ac.tz/about_us/index.php (10 April 2013).

World Health Organization (WHO). 2008. Guidelines on the provision of manual wheelchairs in less resourced settings. Geneva: World Health Organization.

Yokoyama, A. 2012. A comparative analysis of institutional capacities for implementing disability policies in East African countries: functions of National Councils for Disability. Disability, CBR\& Inclusive Development, 23(2): 22-40.

Yoon, H. and Kim, S. 2011. Development strategy of the alternative format materials for disabled people in Korea. Aslib Proceedings: new information perspectives, 63(1): 380-398. 